\begin{tabular}{c} 
Volume and Issues Obtainable at Center for Sustainability Research and Consultancy \\
Journal of Business and Social Review in Emerging Economies \\
ISSN: 2519-089X (E): 2519-0326 \\
Volume 3: Issue 2December 2017 \\
CSRᄃ \\
Journal homepage: $\underline{\text { www.publishing.globalcsrc.org/jbsee }}$ \\
\hline
\end{tabular}

\title{
Conceptual Model of Predictors of SMEs' Performance in the Context of Sudan ${ }^{1}$ Osman ElsheikhAbdelrahman, ${ }^{2}$ Zarifah Bt Abdullah, ${ }^{3}$ Zakaria Abas
}

\author{
${ }^{1}$ School of Accounting,College of Business,Universiti Utara Malaysia \\ osmanabde@gmail.com \\ ${ }^{2}$ School of Accounting,College of Business,Universiti Utara Malaysia \\ ${ }^{3}$ School of accounting,College of Business, Universiti Utara Malaysia
}

\begin{tabular}{l}
\hline ARTICLEDETAILS \\
\hline History \\
Revised format: Nov 2017 \\
AvailableOnline: Dec 2017
\end{tabular}

\section{Keywords}

Management accounting,

Costing practices,

Budgeting practices,

Performance measures

practices,

SMEs'performance

\section{JEL Classification:}

M41, M49, P27, P29

\begin{abstract}
Purpose: SMEs' performance in Sudan is in downturn and calls for research-based solution. To address this, this conceptual study proposes a model entailing management accounting practices (costing, budgeting, and performance measures practices) as predictors of SMEs' performance. Also, research findings on the relationship between management accounting practices and performance are inconsistent. Given this, this study proposes a model entailing management accounting practices as determinants of SMEs' performance with moderating role of external business environment.

Design/methodology/approach: This work is theorized based on extensive literature survey through which a conceptual model is developed and discussed. Inconsistent relationship between management accounting practices and performance is valuated and established via published research. Also, moderating role of external business environment is discussed and validated based on contingency theory.

Findings: This paper proposes a conceptual model to serve as an answer to how Sudanese SMEs' performance can be improved through management accounting practices.

Research limitations/implications: The proposed model in this work is based on survey of published research, but it can be empirically solidified further through collection and analysis of relevant data.

Practical implications: The paper can help SMEs' owners/ managers and policy makers to understand how properly-adopted management accounting practices can improve SMEs' performance.

Originality/value: The proposed conceptual framework is an exceptional and all-inclusive model that will expectantly improve the relevant body of literature and serve as useful guide for stakeholders on how the performances of SMEs can be boosted to enable them catch up with the SMEs' performance level of the developed countries in order to boost the economy of Sudan as a nation.
\end{abstract}

(C) 2017 The authors, under a Creative Commons AttributionNonCommercial 4.0

Corresponding author's email address: osmanabde @ gmail.com

Recommended citation:Abdelrahman,O.E., Abdullah,Z. \& Abas,Z., (2017).Conceptual Model of Predictors of SMEs' Performance in the Context of Sudan.Journal of Business and Social Review in Emerging Economies, 3(2) 263-276.DOI:https://doi.org/293-310. 10.26710/jbsee.v3i2.186

\section{Introduction}

Both at the global level and local level, Small and Medium Enterprises (SMEs), as a distinct sector in the 
economy, is considered the springboard for sustaining economic development, and its important roles cannot be underestimated in any developed or developing country (Kuntchev et al., 2012). It is a major provider of employment (Economist \& Unit, 2016; Elasrag, 2012; Kongolo, 2010). Specifically, in Sudan, SMEs provides more than $70 \%$ of job opportunities, makes citizens become very productive, and helps in capital formation (Stevenson, 2010; Gupta, Seetharaman, \& Raj, 2013; Economist Intelligence Unit, 2016). SMEs remains the main source of national income after the secession of South Sudan (Nour, 2011; Thwala et al., 2012; Ajagbe, Enegbuma, Bilau\& Long, 2012).

Nevertheless, Sudan's SMEs is confronted with a number of challenges hampering its performance and eventual collapse of many SMEs. For example, in 2012, 2013, 2014 and 2015, the contribution of SME to Sudan's gross domestic production (GDP) was 62.1 percent, 50.48 percent, 46.54 percent and 38.09 percent respectively (African Development Bank, 2012; Khattab\& Ali 2014; Economist \& Unit, 2016). Also, over 20 percent of Sudanese tanneries representing 49 present in Khartoum State have closed down (Economist Intelligence Unit, 2016). This has adversely affected current economic situation of Sudan as inflation rate is getting higher (18.15 as per August 2016) (Mirgjani, 2016). The dismal performance of Sudanese SMEs has been responsible for the gloomy and depressing performance of country's economy (Stevenson, 2010; Gangi, \&Timan, 2013).

The declining SMEs' performance and the consequent collapse are associated with many issues bordering on high production cost, budgeting impact of environment, lack of performance measurement (Abdalkrim, 2013), external business environment (Eifert, Gelb \& Ramachandran, 2005; Ramachandran, Gelb \& Shah, 2009;CGA, 2010), inadequate budgeting and performance measurement (Ardic et al., 2011; Abdulsaleh \& Worthington, 2013b), inadequate manpower, poor savings culture (Thwala, Ajagbe, Enegbuma, Bilau, \& Long, 2012), constraint in sourcing for the required fund, societal and transparency problems (Meinel\&Leifer, 2011), and inability to secure the required information (Tiemo 2012).

Furthermore, Churchill and Lewis (1983) and Yassir Abdel Wahied (2015) stressed that there are many causes of failure of the businesses at the initial stage. These causes include lack of adequate working capital, raw materials, skilled manpower, volatile business environment, bad government policies, high tax rates, and unfavourable exchange rate are some of the problems confronting SMEs. In addition, Stevenson (2010) posited that lack of adequate application of accounting and management accounting practices by SMEs leads to their high rate of failure. Many small firms lack favourable business environment and fail to develop initial plan for costing and budgeting while those that establish the plan for costing and budgeting fail to continually adjust and use it as a benchmarking tool (Ihua, 2009; Ropega, 2011; Hope \& Fraser, 2013).

Besides, survey of the existing literature (e.g. Brijlal et al., 2014;Tayles, Pike \& Sofian, 2007; Scapens, 1990) indicates shortage of empirical studies that integrate costing, budgeting, and performance measurement practices with moderating variable of the external business environment, although few studies have indicated how costing, budgeting, performance measurement practices, and external business environment can stimulate profit growth and drive forward performance. Also, there is dearth of research regarding the use of external business environment as moderator in the context of SMEs (Drury \& Tayles,1995; Alkizza\& Akbar, 2006; CGA, 2010;Shehu\& Mahmood, 2014).In Sudan, the application of management accounting practices (MAPs) in SMEs is limited, and there are few studies relating MAPs usage to the performance of SMEs. This gap needs to be filled up, because the information provided may guide government policy towards the SMEs sector. Lack of data on MAPs and SMEs' efficiency and effectiveness may hamper SMEs' ability to contribute meaningfully to the Sudanese economy (Thwala et al., 2012).

Owing to the facts and figures given above, there is need for Sudanese SMEs to upsurge and enhance its performance level and its competitive advantage, as this will enable it to catch up with the SMEs' performance level of the advanced countries, and in turn make the economy of the country booms. Thus, 
research, which look into how Sudanese SMEs performance can be enhanced in relation to the discerned management accounting issues, bordering on costing practices, budgeting practices, performance measurement practices, and business environment aspects, is necessary.

According to Uyar (2010), management accounting especially in the context of SMEs sector should be given attention in the search and development of innovative competitive strategies. Garg, Ghosh,Hudick and Nowacki (2003); Douglas Clinton CMA and CFM (2012); Yalcin (2012); Sunarni (2013) and Ahmad (2013) revealed that despite the developments in management accounting theory, the practice remains unchanged as companies still use the traditional management accounting practices. The Sudanese SMEs relies heavily on traditional management accounting practices, hence, the adoption rates of recently developed or advanced practices are low and slow. In Sudan, there appears not to be many empirical studies on the indispensability of management accounting practices (Waweru, Hoque\&Uliana, 2005; Al \& McLellan, 2011).

Thus, this conceptual study proposes a conceptual model of MAPs, business environment and Sudanese SMEs' performance. Also, this study aims at examining the effect of MAPs, external business environment on Sudanese SMEs' performance. Next section presents the review of the literature conducted for the development of the proposed model.

\section{Literature Review}

Based on the identified issues in the introductory sections of this paper, there is need to examine relationship between costing, budgeting, performance measurement practices, external business environment and SMEs' performance in the context of Sudan.

\subsection{Overview of the Variables of the Study}

SMEs mean different things to different authors, in different ways and in different contexts. Different countries have their peculiar meanings grounded on the expected role of SMEs in that country. Therefore, many countries consider their levels of industrial development and other economic factors in defining SMEs (Abor \&Quartey, 2010).

SMEs in Sudan entails micro, small and medium businesses. The micro businesses are those with a labour size of not more than ten workers, and the total cost of not more than five million Sudanese pound (SDG), excluding land but including working capital; small businesses involve all the firms with a labor size of between ten to forty-nine workers, with a total cost of five million SDG, but not exceeding fifty million SDG, excluding cost of land but including working capital; medium-scale businesses are those enterprises with a labor size between fifty and two hundred and forty-nine, with a total cost above fifty million SDG, but not exceeding five hundred million SDG, excluding cost of land but including working capital (Central Bank of Sudan [CBS], 2007].

SMEs' performance is process of activities through which the objectives of the firm are achieved consistently in an efficient and effective manner (Anthony, 2005; Kuntchev, Ramalho, Rodríguez-Meza \& Yang, 2012; Gurdon, 2013).Smith (2005) and MelnykBititci, Platts, Tobias and Andersen (2014) posits that performance is a scientifically coined word which helps in measuring the efficiency and effectiveness of production and services that assists in the realization of profit. To enhance competitive advantage, many criteria have been used for the assessment of performance of SMEs and other organisations. However, performance in small companies is viewed from two perspectives: the monetary (financial) and the non-monetary (non- financial) measures (Elhiraika, 2004; Abdel-Maksoud, Dugdale, Luther, 2005; Kuntchev, Ramalho, Rodríguez-Meza \& Yang, 2012).

Moreover, review of scholastic research signifies that there is no single perfect design for management accounting practices (MAPs), but the best design relies on the circumstances in which the company operates (Tayles et al., 2007). Given this, Libby and Lindsay (2007) and Ahmadi and Ahmadi (2011). submit that it is on the basis of accounting for costing, budgeting and performance measurement practices 
that success of the business is measured and on which investors can find out whether or not their investment is safe and will produce a reasonable proceed for them.

Costing practices is a kind of philosophy and behaviours directed towards identification of needs of the targeted company with decreasing cost, it examines company's ability to control production costs (Ahrens \& Chapman, 2007; Busco, Quattrone\&Riccaboni, 2007; Abugalia, 2011). costing practices are classified into seven items: variable (or marginal) costing, full (absorption) costing, standard costing, activity-based costing (ABC), target costing, life-cycle costing and quality cost reporting. As for the budgeting practices, it refers to the process of leveraging and detecting collective costs in the company to assist it compete favourably. According to Steed and $\mathrm{Gu}$ (2009) and Phaup and Kirschner (2010) budgeting practices is a complex, social-technical system that consists of various methods of budgets that is used in sharing and controlling in decision making process. It includes: (1) capital budget, (2) administrative expenses budget, (3) direct materials budget, (4) direct labor budget, (5) overheads budget, (6), sales budget (7) Activity- based budgeting, and (8) production budget.

Performance measurement practices (PMP) denotes the ideal system through which organization monitors its internal working system for the purpose of understanding the contribution of each department towards attaining overall goals (Verbeeten, 2008). According to Gomes et al., (2011), performance measurement practices' essence is to ensure that the organizational activities are efficiently in line with the overall objectives of the organization. Performance measurement practices measures include: (1) balanced scorecard; (2) customer satisfaction; (3) non-financial measures; (4) employees' satisfaction; (5) return on investment (or return on capital employed) (Sharma, Bhagwat \&Dangayach, 2005; Nudurupati, Bititci, Kumar \& Chan, 2011 ;Eltinay, Masri\&Govindaraju, 2013; Melnyk, Bititci, Platts Tobias \& Andersen, 2014).

Furthermore, business environment refers to the surroundings in which business operates, and which is ever-changing, compounding and competitive in nature (Ishengoma\&Kappel, 2011). Business environment is the set of norms, ethics, legal and governing frameworks, and the overall policy conditions that set rules for conduct of business and influence both positively and negatively the performance of company, the flow of investment, factor productivity, and the cost of operating a business. These can either be from both internal or external settings, and it can affect the smooth running as well as function of an organization (Abugalia, 2011; Shehu\& Mahmood, 2014). Dynamic environmental dimensions arise from the changes in major operating variables such as market and industry, economic, political, technology and other social forces.

\subsection{Costing Practices and Performance}

Numerous studies have been conducted with focus on costing practices (CPs) and performance. Among these studies are Chenhall and Langfield-Smith (1998) whose findings indicate significant and positive relationship between costing practices and performance. Similarly, Guilding, Lamminmaki and Drury (1998) who conducted their research on a sample of fifty-three single businesses, found a positive relationship between costing practices and performance.

Furthermore, in the seminal work done by Joshi (2001) positive and significant nexus among costing practices and company performance was found. Similar finding was also found by Luther and Longden (2001) in their research on relationship between costing practices and performance in the context of a developing economy, using a survey questionnaire administered on one hundred and sixty-two manufacturing and Service Company.

Lamminmaki and Drury (2001) reported a significant and positive influence of costing practices on small company performance. Tornberg, Jämsen and Paranko (2002) in their study on the effect of costing practices on performance in service firms, examined the association between costing practices and performance in the hospitality businesses. Two hundred and one data were generated through survey questionnaire and the preliminary questions were pre-tested on thirty hotel chief executives who joined an executive development program at a leading hotel and restaurant in the north- eastern USA. The finding shows that costing practices is positively related to both non-financial measures of performance (service 
quality, customer satisfaction, and employee satisfaction) and financial measures of performance (occupancy rate, gross operating profit, and market segment). This research establishes a strong positive connection between costing practices and all forms of performance.

Arai (2006) examined three hundred and fifty-three owner/ managers in Japan. A structural equation modeling and survey design was used. The finding of their study reported an important linkage between costing practices and small sized service retailer performance. Rattray et al., (2007) in their Meta-analytic study on costing practices, employed a quantitative approach using correlation and multivariate analyses. The finding of their study reported that relationship between costing practices and performance is positive and stronger in the sampled manufacturing firms.

More so, substantial studies, including Akyol et al., (2007), Banker et al., (2008), Hamood et al., (2011), Fullerton et al., (2014), Chapman et al., (2014) etc., have established positive nexus between conducted a research on the association between costing practices and performance.

However, many other studies such as King et al., (2010) Mahama et al., (2013). Siguenza-Guzman et al., (2016).reported mixed findings in which significant negative relationship or no significant relationship were found between costing practices and performance.

Moreover, majority of the research are conducted in US, UK and some nations other than Sudan while large number of them were conducted on large firms. Since the findings of the substantial reviewed research indicate positive relationship between costing practices and performance, it can be inferred that same result will be arrived at if the relationship is tested in the context of Sudan's SMEs.

Given the above explication, this conceptual paper makes the following proposition:

P1: There is a significant and positive relationship between costing practices and SMEs' performance in Sudan.

\subsection{Budgeting Practices and Performance}

Considerable studies have established the linkage between budgeting practices and company performance. Pike (1996) examined the relationship between budgeting practices, environmental uncertainty and company performance and found that budgeting practices are directly related to various intermediate measures of strategic organisational performance namely: budgets, product leadership and operational excellence, and that those intermediate measures are, in turn, associated with company performance. Based on this evidence, the researchers added that as long as budgeting practices enhance intermediate organisational performance, positive company performance will be the outcome.

The study by Burritt (2004) indicates that small companies can benefit from operational budgeting practices for sustainable competitiveness. Hansen et al., (2004).investigated the relationship between budgeting practices and company performance by empirically investigated 78 companies in US and found positive relationships between budgeting practices and performance.

Nevertheless, studies results show that SMEs still lacks in budgeting practices. There are various reasons for this. Those reasons include lack of financial and non-financial resources, less top management promise, shortage of financial performance related organizational infrastructure (Chief Knowledge Officer or Chief Information Officer), and misunderstanding about budgeting practices, benefits and its implementation. Less work has been done about budgeting practices in SMEs due to the misunderstanding that knowledge management can be similarly practiced in SMEs as it can be practiced in large organizations (Dugdale\&Lyne, 2006). It is observed that SMEs would benefit from the budgeting practices (Verbeeten, 2006).

Several other research on budgeting practices-performance nexus include Van der Haddad et al., (2010), King et al., (2010), Robinson et al., (2013), Bleyen et al., (2015) etc. All of these researches establish significant and positive relationship between budgeting practices and company performance, although those studies were done in different context excluding Sudan.

Going by the above discussion, this conceptual paper proposes that:

P2: There is a significant and positive relationship between budgeting practices and SMEs' performance in Sudan. 


\subsection{Performance Measurement Practices and Performance}

Numerous studies have established the linkage between performance measurement practices (PMPs) and company performance. According to Folan and Browne (2005), a performance measurement practice is positively related to performance. PMPs may be more strongly related to performance when it is pooled with both the appropriate plan and the proper environmental conditions, and this study paves way for the emergence of other related empirical studies on performance measurement practices and company performance. The finding of Gomes et al., (2006) supported the previous performance measurement practices literature that established the positive association between performance measurement practices and performance relationship.

The studies of Lichiello and Turnock (1999), Parker (2000), Hussain et al., (2002), Salas et al., (2008), Verbeeten (2008), Kim and Kim (2009), Nudurupati et al., (2011) etc. confirmed positive relation between performance measurement practices and company performance.

Nevertheless, Gomes et al., (2011); Bititci et al., (2012) established a negative relationship between performance measurement practices and performance. De Vries (2010) and Delgado Ferraz and GallardoVázquez (2016) findings indicate mixed findings with regards to connection between the two variables. Powell (2004) study showed inconsistent results regarding the relationship between performance measurement practices and performance. Studies conducted by O'Sullivan and Abela (2007); Garengo and Bititci (2007) found positive relationship between performance and performance measurement but Moxham (2009) noted no relationship between the two variables.

It is also noteworthy that most performance measurement practices studies were conducted in Europe and Latin America and US (Ben Hadj Salem Mhamdia, 2013), and substantial reviewed research indicate positive relationship between PMPs and performance. In addition, some researchers (Azfar et al., 2014; Micheli\& Mari, 2014) suggested research in other in other countries with different socio- cultural situation from that of the US and other developed nations.

Based on the above arguments, this study proposes the following:

P3: There is a significant and positive relationship between performance measurement practices and SMEs' performance in Sudan.

\subsection{External Business Environment Variable as a Moderator}

Moderating variable is widely used in business research areas, as it affects and strengthens the relationship between independent variable (predictor) and dependent variables (Shields et al., 2000). Organization's strategies, its capabilities and resources aligned with the external business environmental factors determine firm's long-term profit (Powell, 1992; Fuchs et al., 2000; Beer et al., 2005). Several researchers suggested that external business environment moderate the connection between organizational strategies and performance of a company (Dess\& Beard,1984; Zahra \& Bogner,1999; Li and AtuaheneGima. 2001).

Sila and Ebrahimpour (2002), based on their comprehensive review of the management accounting practices literature, identified that research findings are inconsistent regarding the relationship between management accounting practices and company performance. Furthermore, Dosch and Wilson (2010), in their empirical investigation on the relationship between costing practices to company performance, observed that costing practices is incapable to directly increase business performance without the moderation of business environment. Likewise, it has been contended that company performance and budgeting practices relationship depends on both factors of external business environment and internal organizational processes (Tang et al., 2008). According to Martins and Rialp (2013) external business environment is always highlighted as an important contextual factor in the budgeting practices and performance relationship.

Like costing and budgeting, performance measurement practices (PMPs) is equally considered as one of the very important factor that contribute to firm performance and regarded as a main source to profit 
growth and enhance performance (Bryson \& Daniels,1998; Johnson et al., 2007; Klapper\& Parker, 2011). Given the inconsistency regarding research findings on PMPs and performance nexus, studies have suggested that the effect of performance measurement practices on performance depends on external environmental conditions (Britton and Worthington (2010); Fereidouni et al., 2010). Performance measurement practices are required to focus on those external business environmental factors that are expected to affect their ability towards the enhancement of customer satisfaction (Wong et al., 2014).

Adeoye and Elegunde (2012) argued that the proper alignment between key organizational factors with the context or environment leads to better performance. The significance of proper alignment of practices with the environment refers that companies must develop those capabilities and characteristics that will give them ability to cope with their environments Gupta (2013); Otache and Mahmood (2015) highlighted that firm's outcome should not be measured based on its characteristics (i.e. management style. structure, etc.) but rather results should be determined from the fit between firm's dimensions within a specific environment.

Based on the above explication, this conceptual research makes the following propositions:

P4: External business environment moderates the relationship between costing practices and SMEs' performance in Sudan

P5: External business environment moderates the relationship between budgeting practices and SMEs' performance in Sudan.

P6: External business environment moderates the relationship between performance measurement practices and SMEs' performance in Sudan.

\section{Underpinning Theory of the Proposed Conceptual Model}

This proposed conceptual model which proposes that management accounting practices (costing, budgeting, performance measurement practices) and performance of SMEs are interrelated via the moderating role of external business environment is underpinned by the resource-based view which posits that performance of an organization is affected by its resources and capabilities. Firms are able to achieve better performance through the effective use of their organizational resources and strategic capabilities (i.e. costing, budgeting, performance measurement practices).

Strategic capabilities i.e. costing, budgeting, performance measurement practices are a pool of internal resources aimed at achieving profit growth (King et al., 2010). So, these rare and distinctive combinations of strategic resources within a firm have potential to enhance company performance and to achieve profit growth (Antony \& Bhattacharyya, 2010). It is also posited that firms should work towards the establishment of the relationship among external business environment, internal capabilities and strategies for the maximization of profit, growth and improved performance (Kurien\& Qureshi, 2011).

Moreover, the concept of "fit" or "match" is the basic premise of the contingency theory. Therefore, research scholars of )the contingency research and management, such as Otley (1980); HaldmaandLääts (2002); Scapens (2006); Covaleski et al., 2006); Abdel-Kader and Luther (2008) emphasized the necessity of the fit between the organizational strategy and some of the organizational variables as the key prerequisite for company's performance. Fullerton et al., (2014) observed that there can be improvement in company performance if there is an effective alignment of the key management accounting variables. Contingency theory posits that the firm structure or strategy are varies based on its contextual situation. 


\section{Proposed Conceptual Research Model}

Based on the discussion in the preceding sections, this work proposes a conceptual model which indicates that management accounting practices (costing, budgeting, performance measurement practices) and performance of SMEs are connected via the moderating role of external business environment. This is illustrated in the figure below:

\section{Figure:1}

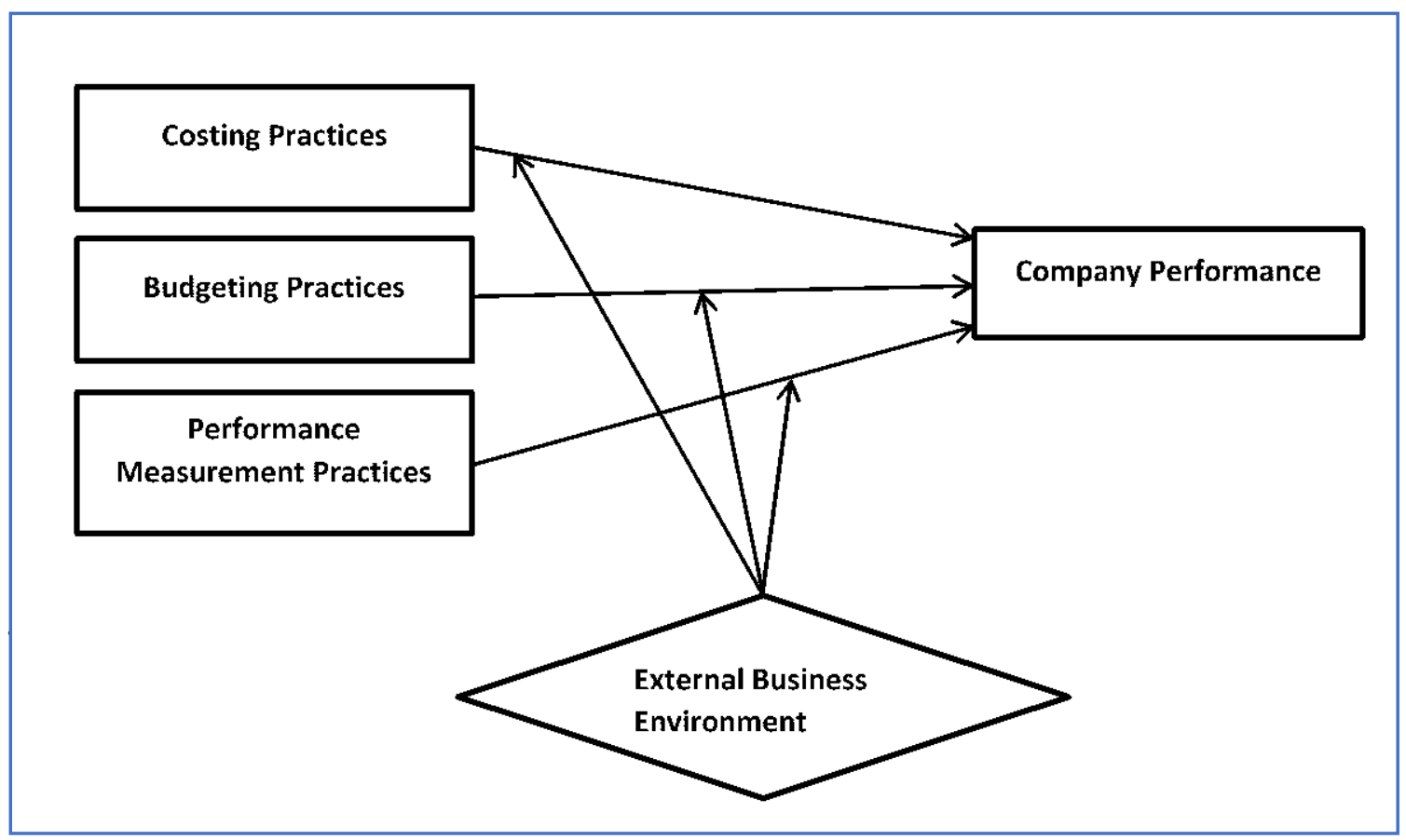

This conceptual work makes contributions in many ways including theoretical, contextual, and managerial contributions. It posits the moderating role of external business environment in the relationship between management accounting practices (costing, budgeting, performance measurement practices) and performance of SMEs. Thus, it contributes to the present body of knowledge in the research area. It can equally be a useful guide for stakeholders and policy makers in Sudan on how the performances of SMEs can be enhanced to enable them catch up with the SMEs' performance level of the advanced countries in order to boost the economy of Sudan as a nation.

\section{References}

Abdalkrim, G. M. (2013). The Impact of Strategic Planning Activities on Private Sector Organizations Performance in Sudan: An Empirical Research. International Journal of Business and Management, 8(10), 134-143. https://doi.org/10.5539/ijbm.v8n10p134

Abdel-Kader, M., \& Luther, R. (2008). The impact of firm characteristics on management accounting practices: A UK-based empirical analysis. British Accounting Review, 40(2008), 2-27. https://doi.org/10.1016/j.bar.2007.11.003.

Abdulsaleh, A. M., \& Worthington, A. C. (2013). Small and Medium-Sized Enterprises Financing: A Review of Literature. International Journal of Business and Management, 8(14), 36-55. https://doi.org/10.5539/ijbm.v8n14p36

African Development Ban. (2012). Sudan, 13(1), 38-43. https://doi.org/10.1108/14678041211228689

Capacity, B., Project, S., Bank, W., \& Hassan, A. (2015). Faculty of Economic and Social Studies , University of Khartoum ( $\mathrm{U}$. of K .) in Collaboration with the Ministry of Finance and National Economy Overview of the Salient Elements of Sudan's Investment Encouragement Act 2013, (1956), 0-6.

Economist, T., \& Unit, I. (2016). Worldwide Cost of Living 2014: A special report from the Economist 
Intelligence Unit. The Economist, 67(1), 14.

Elasrag, H. (2012). The Developmental Role of SMEs in the Arab Countries. SSRN Electronic Journal, 0-14. https://doi.org/10.2139/ssrn.2127954

Gupta, P., Seetharaman, A., \& Raj, J. R. (2013). The usage and adoption of cloud computing by small and medium businesses. International Journal of Information Management, 33(5), 861-874. https://doi.org/10.1016/j.ijinfomgt.2013.07.001

Kongolo, M. (2010). Job creation versus job shedding and the role of SMEs in economic development. Journal of Business, 4(11), 2288-2295. Retrieved from http://www.academicjournals.org/ajbm/PDF/pdf2010/4Sept/Kongolo.pdf

Meinel, C., \& Leifer, L. (2011). Design Thinking Research. Design Thinking: Understand, Improve, Apply. https://doi.org/10.1016/B978-0-12-387667-6.00013-0

Thwala, W. D., Ajagbe, M. A., Enegbuma, W. I., Bilau, A. A., \& Long, C. S. (2012). Sudanese Small and Medium Sized Construction Firms : An Empirical Survey of Job Turnover, 2(8), 7414-7420.

Abdalkrim, G. M. (2013). The Impact of Strategic Planning Activities on Private Sector Organizations Performance in Sudan: An Empirical Research. International Journal of Business and Management, 8(10), 134-143. https://doi.org/10.5539/ijbm.v8n10p134.

Abdalkrim, G. M. (2013). The impact of strategic planning activities on private sector organizations performance in Sudan: An empirical research. International Journal of Business and Management, $8(10)$, p134.

Abdel-Kader, M., \& Luther, R. (2006). Management accounting practices in the British food and drinks industry. British Food Journal, 108(5), 336-357.

Abdel-Kader, M., \& Luther, R. (2008). The impact of firm characteristics on management accounting practices: A UK-based empirical analysis. British Accounting Review, 40(2008), 2-27. https://doi.org/10.1016/j.bar.2007.11.003.

Abdel-Kader, M., \& Luther, R. (2008). The impact of firm characteristics on management accounting practices: A UK-based empirical analysis. The British Accounting Review, 40(1), 2-27.

Abdel-Maksoud, A., Dugdale, D., Luther, R.G., (2005). Non-financial performance measurement in manufacturing companies. British Accounting Review 37, 262-297.

Abdulsaleh, A. M., \& Worthington, A. C. (2013). Small and Medium-Sized Enterprises Financing: A Review of Literature. International Journal of Business and Management, 8(14), 36-55. https://doi.org/10.5539/ijbm.v8n14p36.

Abugalia, M. (2011). The influence of business environment on the effectiveness of management accounting practices: evidence from Libyan companies (Doctoral dissertation, University of Huddersfield).

Adeoye, A. O., \& Elegunde, A. F. (2012). Impacts of external business environment on organisational performance in the food and beverage industry in Nigeria. British Journal of Arts and Social Sciences, 6(2), 194-201.

African Development Bank. (2012). Sudan, 13(1), 38-43. https://doi.org/10.1108/14678041211228689

Ahmad, K. (2013). The adoption of management accounting practices in Malaysian small and mediumsized enterprises. Asian Social Science, 10(2), 236.

Ahmadi, A.A., \& Ahmadi, F. (2011). The role of management accounting in business performance improvement. Interdisciplinary Journal of Contemporary Research in Business, 3(7), 560-567.

Ahrens, T., \& Chapman, C. S. (2007). Management accounting as practice. Accounting, Organizations and Society, 32(1), 1-27.

Ajagbe, M. A., Enegbuma, I. W., Bilau, A. A., \& Long, C. S. (2012). Sudanese small and medium sized construction firms: an empirical survey of job turnover.

Akyol, D. E., Tuncel, G., \& Bayhan, G. M. (2007). A Comparative Analysis of Activity-Based Costing and Traditional Costing. International Journal of Mechanical, Aerospace, Industrial, Mechatronic and Manufacturing Engineering, 1(3), 13 6-139.

Al, S. F. A., \& McLellan, J. D. (2011). Management Accounting Practices in Sudan--A Transitional Economy Country. Journal of Accounting, Business \& Management, 18(2). 
Alkizza, A., \& Akbar, S. (2006). The Impact of the Business Environment on Management Accounting Practices: Libyan Evidence. Nikolaos G. Theriou, Vassilios Aggelidis, Dimitrios I. Maditinos, Georgios N. Theriou, Testing the Relation Between Beta and Re-turns in the Athens Stock Exchange: A Second Attempt 1 Robert W. McGee, Corporate Governance and the Timeliness of Financial Reporting: A Case Study of the Russian Energy, 56.

Anthony, B.N.O. (2005). Small and Medium Enterprises in Sudan: Problems and Prospects. An Unpublished Ph.D Thesis, St Clements University.

Antony, J. P., \& Bhattacharyya, S. (2010). Measuring organizational performance and organizational excellence of SMEs-Part 1: a conceptual framework. Measuring Business Excellence, 14(2), 3-11.

Arai, K. (2006). Reforming Hospital Costing Practices in Japan: an Implementation Study. Financial Accountability \& Management, 22(4), 425-451. https://doi.org/10.1111/j.1468-0408.2006.00433.x.

Ardic, O. P., Mylenko, N., \& Saltane, V. (2011). Small and medium enterprises: A cross-country analysis with a new data set. World Bank Policy Research Working Paper Series, Vol.

Azfar, K. R. W., Khan, N., \& Gabriel, H. F. (2014). Performance Measurement: A Conceptual Framework for Supply Chain Practices. Procedia - Social and Behavioral Sciences, 150, 803-812. https://doi.org/10.1016/j.sbspro.2014.09.089.

B Douglas Clinton CMA, C. P. A., \& CFM, C. (2012). Roles and practices in Management accounting: 2003-2012. Strategic Finance, 94(5), 37.

Banker, R. D., Bardhan, I. R., \& Chen, T. Y. (2008). The role of manufacturing practices in mediating the impact of activity-based costing on plant performance. Accounting, Organizations and Society, 33(1), 1-19. https://doi.org/10.1016/j.aos.2006.12.001.

Ben Hadj Salem Mhamdia, A. (2013). Performance measurement practices in software ecosystem. International Journal of Productivity and Performance Management, 62(5), 514-533. https://doi.org/10.1108/IJPPM-09-2012-0097.

Bititci, U., Garengo, P., D??rfler, V., \& Nudurupati, S. (2012). Performance Measurement: Challenges for Tomorrow. International Journal of Management Reviews, 14(3), 305-327. https://doi.org/10.1111/j.1468-2370.2011.00318.x.

Bleyen, P., Lombaert, S., \& Bouckaert, G. (2015). Measurement, incorporation and use of performance information in the budget a methodological survey approach to map performance budgeting practices in local government. Society and Economy, 37(3), 331-355. https://doi.org/10.1556/204.2015.37.3.2.

Brijlal, P., Enow, S., \& Isaacs, E. B. (2014). The use of financial management practices by small, medium and micro enterprises: a perspective from South Africa. Industry and Higher Education, 28(5), 341350.

Britton, C., \& Worthington, I. (2010). Business Environment. Discovery, 9, 99-120. https://doi.org/10.1016/B978-1-4557-3189-3.00010-5.

Bryson, J. R., \& Daniels, P. W. (1998). Business Link, strong ties, and the walls of silence: small and medium-sized enterprises and external business-service expertise. Environment and Planning C: Government and Policy, 16(3), 265-280.

Busco, C., Quattrone, P., \& Riccaboni, A. (2007). Management accounting: issues in interpreting its nature and change. Management Accounting Research, 18(2), 125-149.

Capacity, B., Project, S., Bank, W., \& Hassan, A. (2015). Faculty of Economic and Social Studies , University of Khartoum ( $\mathrm{U}$. of K .) in Collaboration with the Ministry of Finance and National Economy Overview of the Salient Elements of Sudan's Investment Encouragement Act 2013, (1956), 0-6.

Central Bank of Sudan Annual Report, (2007).

CGA, H. C. B. (2010). External environmental analysis for small and medium enterprises (SMEs). Journal of Business \& Economics Research, 8(10), 19.

Chapman, C. S., Hopwood, A. G., \& Shields, M. D. (Eds.). (2006). Handbook of management accounting research (Vol. 1). Elsevier.

Chapman, C., Kern, A., \& Laguecir, A. (2014). Costing practices in healthcare. Accounting Horizons. https://doi.org/10.2308/acch-50713.

Chenhall, R. H., \& Langfield-Smith, K. (1998). Adoption and benefits of management accounting 
practices: an Australian study. Management accounting research, 9(1), 1-19.

Covaleski, M., Evans, J. H., Luft, J., \& Shields, M. D. (2006). Budgeting research: three theoretical perspectives and criteria for selective integration. Handbooks of management accounting research, 2 , 587-624.

De Vries, M. S. (2010). Performance measurement and the search for best practices. International Review of Administrative Sciences, 76(2), 313-330. https://doi.org/10.1177/0020852309365668.

Delgado Ferraz, F. A., \& Gallardo-Vázquez, D. (2016). Measurement tool to assess the relationship between corporate social responsibility, training practices and business performance. Journal of Cleaner Production, 129, 659-672. https://doi.org/10.1016/j.jclepro.2016.03.104.

Drury, C., \& Tayles, M. (1995). Issues arising from surveys of management accounting practice. Management Accounting Research, 6(3), 267-280.

Dugdale, D., \& Lyne, S. (2006). Budgeting practice and organisational structure executive summaries. Chartered Institute of Management Accountants, 6(4), 1-6.

Dyer, J. H., \& Chu, W. (2003). The role of trustworthiness in reducing transaction costs and improving performance: Empirical evidence from the United States, Japan, and Korea. Organization science, 14(1), 57-68.

Economist, T., \& Unit, I. (2016). Worldwide Cost of Living 2014: A special report from the Economist Intelligence Unit. The Economist, 67(1), 14.

Eifert, B., Gelb, A., \& Ramachandran, V. (2005). Business environment and comparative advantage in Africa: Evidence from the investment climate data. Banque Mondiale, Washington: DC, 195-233.

Elasrag, H. (2012). The Developmental Role of SMEs in the Arab Countries. SSRN Electronic Journal, 0-14. https://doi.org/10.2139/ssrn.2127954.

Eltinay, N. B., Masri, R., \& Govindaraju, V. C. (2013). Performance Measurement Usage in Developing Countries: The Case of Banking Sector in Sudan. Management, 3(7), 484-490.

Fereidouni, H. G., Masron, T. A., Nikbin, D., \& Amiri, R. E. (2010). Consequences of External Environment on Entrepreneurial Motivation in Iran. Asian Academy of Management Journal, 15(2), 175-196.

Retrieved

from http://search.ebscohost.com/login.aspx?direct=true \&db=buh\&AN=53337999\&site=ehostlive.

Folan, P., \& Browne, J. (2005). A review of performance measurement: Towards performance management. Computers in Industry. https://doi.org/10.1016/j.compind.2005.03.001.

Fullerton, R. R., Kennedy, F. A., \& Widener, S. K. (2014). Lean manufacturing and firm performance: The incremental contribution of lean management accounting practices. Journal of Operations Management, 32(7-8), 414-428. https://doi.org/10.1016/j.jom.2014.09.002.

Gangi, Y. A., \& Timan, E. (2013). An empirical investigation of entrepreneurial environment in Sudan. World Journal of Entrepreneurship, Management and Sustainable Development, 9(2/3), 168-177.

Garengo, P., \& Bititci, U. (2007). Towards a contingency approach to performance measurement: an empirical study in Scottish SMEs. International Journal of Operations \& Production Management, 27(8), 802-825. https://doi.org/10.1108/01443570710763787.

Garg, A., Ghosh, D., Hudick, J., \& Nowacki, C. (2003). Roles and practices in management accounting today. Strategic Finance, 85(1), 30.

Gomes, C. F., Yasin, M. M., \& Lisboa, J. V. (2006). Performance measurement practices in manufacturing firms: an empirical investigation. Journal of Manufacturing Technology Management, 17(2), 144-167. https://doi.org/10.1108/17410380610642241.

Gomes, C. F., Yasin, M. M., \& Lisboa, J. V. (2011). Performance measurement practices in manufacturing firms revisited. International Journal of Operations \& Production Management, 31(1), 5-30. https://doi.org/10.1108/01443571111098726.

Guilding, C., Lamminmaki, D., \& Drury, C. (1998). Budgeting and standard costing practices in New Zealand and the United Kingdom. The International Journal of Accounting, 33(5), 569-588.

Gupta, A. (2013). Environmental and pest analysis : An approach to external business environment. International Journal of Modern Social Sciences, 1(2), 34-43.

Gupta, J., Wilson, N., Gregoriou, A., \& Healy, J. (2014). The value of operating cash flow in modelling 
credit risk for SMEs. Applied Financial Economics, 24(9), 649-660.

Gupta, P., Seetharaman, A., \& Raj, J. R. (2013). The usage and adoption of cloud computing by small and medium businesses. International Journal of Information Management, 33(5), 861-874. https://doi.org/10.1016/j.ijinfomgt.2013.07.001.

Gurdon, C. G. (2013). The economy of Sudan and recent strains. Sudan Nimeiri, 18, 18-33.

Haddad, K., William, S., \& Wu, A. (2010). Capital Budgeting Practices of Non-Industrial Firms. The Journal of International Management Studies, 5(1), 178-182. https://doi.org/10.1080/00137918608902945.

Haldma, T., \& Lääts, K. (2002). Contingencies influencing the management accounting practices of Estonian manufacturing companies. Management Accounting Research, 13(4), 379-400.

Hamood, H. H., Omar, N., \& Sulaiman, S. (2011). Target Costing Practices: a Review of Literature. AsiaPacific Management Accounting Journal, 6(1), 25-46. Retrieved from http://search.ebscohost.com/login.aspx?direct=true\&db=bth\&AN=70138188\&lang=ptbr\&site $=$ ehost-live.

Hansen, S. C., \& Van der Stede, W. A. (2004). Multiple facets of budgeting: An exploratory analysis. Management Accounting Research, 15(4), 415-439. https://doi.org/10.1016/j.mar.2004.08.001.

Hussain, M., \& Hoque, Z. (2002). Understanding non-financial performance measurement practices in Japanese banks. Accounting, Auditing \& Accountability Journal, 15(2), 162-183. https://doi.org/10.1108/09513570210425583.

Ishengoma, E.K., \& Kappel, R. (2011). Business environment and growth potential of micro and small manufacturing enterprises in Uganda. African Development Review, 23(3), 352-365.

Johnson, S., Webber, D. J., \& Thomas, W. (2007). Which SMEs use external business advice? A multivariate subregional study. Environment and Planning A, 39(8), 1981-1997.

Joshi, P. L. (2001). The international diffusion of new management accounting practices: the case of India. Journal of International Accounting, Auditing and Taxation, 10(1), 85-109.

Khattab, S. Ali, (2014). A proposed model for promotion and development of micro, small and medium enterprises in Sudan. International Journal of Business and Social Science, 2(20).

King, R., Clarkson, P. M., \& Wallace, S. (2010). Budgeting practices and performance in small healthcare businesses. Management Accounting Research, 21(1), 40-55. https://doi.org/10.1016/j.mar.2009.11.002.

Klapper, L. F., \& Parker, S. C. (2011). Gender and the business environment for new firm creation. World Bank Research Observer, 26(2).

Kongolo, M. (2010). Job creation versus job shedding and the role of SMEs in economic development. Journal of Business, 4(11), 2288-2295. Retrieved from http://www.academicjournals.org/ajbm/PDF/pdf2010/4Sept/Kongolo.pdf.

Kuntchev, V., Ramalho, R., Rodríguez-Meza, J., \& Yang, J. S. (2012). What have we learned from the Enterprise Surveys regarding access to finance by SMEs?. Enterprise Analysis Unit of the Finance and Private Sector Development, The World Bank Group.

Kurien, G. P., \& Qureshi, M. N. (2011). Study of performance measurement practices in supply chain management. International Journal of Business, Management and Social Sciences, 2(4), 19-34.

Lamminmaki, D., \& Drury, C. (2001). A comparison of New Zealand and British product-costing practices. The International Journal of Accounting, 36(3), 329-347. https://doi.org/10.1016/S00207063(01)00106-6.

Libby, T., \& Lindsay, R. M. (2007). Beyond budgeting or better budgeting?. Strategic Finance, 89(2), 46.

Lichiello, P., \& Turnock, B. J. (1999). Guidebook for Performance Measurement. Policy Analysis, (December), $1-81$.

Retrieved

from http://www.uic.edu/sph/prepare/courses/PHLearning/resources/pmguidebook.pdf.

Luther, R. G., \& Longden, S. (2001). Management accounting in companies adapting to structural change and volatility in transition economies: a South African study. Management Accounting Research, 12(3), 299-320.

Mahama, H., \& Cheng, M. M. (2013). The effect of managers' enabling perceptions on costing system use, psychological empowerment, and task performance. Behavioral Research in Accounting, 25(1), 
89-114. https://doi.org/10.2308/bria-50333.

Maiga, A. S., \& Jacobs, F. A. (2003). Balanced scorecard, activity-based costing and company performance: An empirical analysis. Journal of Managerial Issues, 15(3), 283-301. Retrieved from.

http://proxy1.ncu.edu/login?url=http://search.ebscohost.com/login.aspx?direct=true \&db=buh\&AN=11122 091\&site=ehost-live.

Meinel, C., \& Leifer, L. (2011). Design Thinking Research. Design Thinking: Understand, Improve, Apply. https://doi.org/10.1016/B978-0-12-387667-6.00013-0

Melnyk, S. A., Bititci, U., Platts, K., Tobias, J., \& Andersen, B. (2014). Is performance measurement and management fit for the future?. Management Accounting Research, 25(2), 173-186.

Micheli, P., \& Mari, L. (2014). The theory and practice of performance measurement. Management Accounting Research, 25(2), 147-156.

https://doi.org/10.1016/j.mar.2013.07.005.

Mirgjani, Y. I. (2016). Industrial Development in the Sudan (Doctoral dissertation, University of Khartuom).

Moxham, C. (2009). Performance measurement. International Journal of Operations \& Production Management, 29(7), 740-763. https://doi.org/10.1108/01443570910971405.

Nour, S. M. (2013). Research Methodology and Methods of Data Collection. In Technological Change and Skill Development in Sudan (pp. 115-138). Springer Berlin Heidelberg.

Nour, S. S. O. M. (2011). Assessment of the impact of oil: opportunities and challenges for economic development in Sudan. African Review of Economics and Finance, 2(2), 122-148.

O’Sullivan, D., \& Abela, A. V. (2007). Marketing Performance Measurement Ability and Firm Performance. Journal of Marketing, 71(2), 79-93. https://doi.org/10.1509/jmkg.71.2.79.

Otache, I., \& Mahmood, R. (2015). Corporate entrepreneurship and business performance: The role of external environment and organizational culture: A proposedframework. Mediterranean Journal of Social Sciences, 6(4), 524-531. https://doi.org/10.5901/mjss.2015.v6n4s3p524.

Otley, D. T. (1980). The contingency theory of management accounting: achievement and prognosis. Accounting, Organizations and society, 5(4), 413-428.

Parker, C. (2000). Performance measurement. Work Study, 49(2), 63-66.

https://doi.org/10.1108/00438020010311197.

Pavlatos, O., \& Paggios, I. (2008). Management accounting practices in the Greek hospitality industry. Managerial Auditing Journal, 24(1), 81-98.

Phaup, M., \& Kirschner, C. (2010). Budgeting for disasters: focusing on the good times. OECD Journal on Budgeting, 10(1), 21.

Pike, R. (1996). A longitudinal survey on capital budgeting practices. Journal of Business Finance and Accounting, 23(1), 79-92. https://doi.org/10.1111/1468-5957.00206.

Powell, S. (2004). The challenges of performance measurement. Management Decision, 42(8), 10171023. https://doi.org/10.1108/00251740410555515.

Ramachandran, V., Gelb, A. H., \& Shah, M. K. (2009). Africa's Private Sector: What's Wrong with the Business Environment and what to Do about it. CGD Books.

Rattray, C. J., Lord, B. R., \& Shanahan, Y. P. (2007). Target costing in New Zealand manufacturing firms. Pacific Accounting Review, 19(1), 68-83. https://doi.org/10.1108/01140580710754656.

Robinson, M., Huerta Melchor, O., \& Hawkesworth, I. (2013). Selected budgeting issues in Chile. OECD Journal on Budgeting, 12(3), 1-39. https://doi.org/10.1787/budget-12-5k44tpx5bl48.

Ropega, J. (2011). The reasons and symptoms of failure in SME. International Advances in Economic Research, 17(4), 476-483.

Salas, E., Rosen, M. a., Held, J. D., \& Weissmuller, J. J. (2008). Performance Measurement in Simulation-Based Training: A Review and Best Practices. Simulation \& Gaming, 40(3), 328-376. https://doi.org/10.1177/1046878108326734.

Scapens, R. W. (1990). Researching management accounting practice: the role of case study methods. The British Accounting Review, 22(3), 259-281.

Scapens, R. W. (1990). Researching management accounting practice: the role of case study methods. 
The British Accounting Review, 22(3), 259-281.

Scapens, R. W. (2006). Understanding management accounting practices: A personal journey. The British Accounting Review, 38(1), 1-30.

Shehu, A. M., \& Mahmood, R. (2014). Determining the effect of business environment on small and medium enterprises performance: A SEM Approach. Journal of Economics and Sustainable Development, 5(17), 1-9.

Siguenza-Guzman, L., Auquilla, A., Van den Abbeele, A., \& Cattrysse, D. (2016). Using Time-Driven Activity-Based Costing to Identify Best Practices in Academic Libraries. Journal of Academic Librarianship, 42(3), 232-246. https://doi.org/10.1016/j.acalib.2016.01.005.

Smith, M. (2005). Performance measurement and management: a strategic approach to management accounting.

Steed, E., \& Gu, Z. (2009). Hotel management company forecasting and budgeting practices: A surveybased analysis. International Journal of Contemporary Hospitality Management, 21(6), 676-697.

Stevenson, L. (2010). Private sector and enterprise development: fostering growth in the Middle East and North Africa. IDRC.

Sunarni, C. W. (2013). Management accounting practices and the role of management accountant: Evidence from manufacturing companies throughout Yogyakarta, Indonesia. Review of Integrative Business and Economics Research, 2(2), 616.

Taba, L. M. (2005). Measuring the Successful Implementation of Activity Based Costing (ABC) in the South African Post Office (Doctoral dissertation, UNIVERSITY OF SOUTH AFRICA).

Tayles, M., Pike, R. H., \& Sofian, S. (2007). Intellectual capital, management accounting practices and corporate performance: perceptions of managers. Accounting, Auditing \& Accountability Journal, 20(4), 522-548.

Thwala, D. W., Ajagbe, A. M., Enegbuma, W. I., Bilau, A. A., \& Long, C. S. (2012). Sudanese Small and Medium Sized Construction Firms: An Empirical Survey of Job Turnover. Journal of Basic, Applied Social Research (JBASR), 2(8), 7414-7420.

Tiemo, J. A. (2012). Strategic focus of Nigeria SMSE: More more of emergent or planned. Journal of Emerging Trends in Economics and Management Sciences, 3(3), 229-232.

Verbeeten, F. H. (2008). Performance management practices in public sector organizations: Impact on performance. Accounting, Auditing \& Accountability Journal, 21(3), 427-454.g. Sage.

Verbeeten, F. H. M. (2006). Do organizations adopt sophisticated capital budgeting practices to deal with uncertainty in the investment decision?: A research note. Management Accounting Research, 17(1), 106-120. https://doi.org/10.1016/j.mar.2005.07.002.

Waweru, N. M., Hoque, Z., \& Uliana, E. (2005). A survey of management accounting practices in Sudan. International Journal of Accounting, Auditing and Performance Evaluation, 2(3), 226-263.

Wong, W. P., Hazlina Ahmad, N., Mohd. Nasurdin, A., \& Mohamad, M. N. (2014). The impact of external environmental on business process management and organizational performance. Service Business, 8, 559-586. https://doi.org/10.1007/s11628-013-0207-9.

Yalcin, S. (2012). Adoption and benefits of management accounting practices: an inter-country comparison. Accounting in Europe, 9(1), 95-110.

Yassir AbdelWahied, H. (2015). Development Constraints in the Developing Countries (Sudan): a Case Study (Doctoral dissertation, UOFK). 